\title{
Why, How and What do Organizations Achieve with the Implementation of Environmental Management Systems?-Lessons from a Comprehensive Review on the Eco-Management and Audit Scheme
}

\author{
Patrícia Tourais and Nuno Videira * \\ CENSE-Center for Environmental and Sustainability Research, Departamento de Ciências e Engenharia do \\ Ambiente, Faculdade de Ciências e Tecnologia, Universidade NOVA de Lisboa, Campus de Caparica, \\ 2829-516 Caparica, Portugal; ptf@fct.unl.pt \\ * Correspondence: nmvc@fct.unl.pt; Tel.: +351-212-948-397 \\ Academic Editor: Pauline Deutz \\ Received: 1 December 2015; Accepted: 14 March 2016; Published: 18 March 2016
}

\begin{abstract}
The Eco-Management and Audit Scheme (EMAS) was established in 1993 in the European Union as a voluntary instrument facilitating the implementation of organisational environmental policies and management of environmental aspects. We present a comprehensive literature review on EMAS research, organized according to three broad questions: Why do organisations choose EMAS? How is the scheme implemented and adapted to organisational characteristics? And what results are achieved? We have built analysis matrices to critically review 80 articles published over the past two decades and to identify the recurrent research themes addressing each question. We found that the decision to adopt EMAS is motivated by a set of internal and external factors, compounded by the potential of an organisation to combine the scheme with other EMS standards and environmental management tools. These themes are the ones most extensively covered by existing literature. To answer the question on how organisations implement and adapt to the scheme, two themes have been identified covering EMS planning and operation issues and sectoral approaches. Results show that the focus has been put on development of methods for assessing the significance of environmental aspects, implementing environmental policies and developing indicators for tracking performance and elaborating environmental statements. The development of sectoral approaches that adapt EMAS to characteristics of different economic activity sectors is also emerging as a critical research development. Finally, the themes addressing results achieved with EMAS implementation have only recently surfaced in the literature. The achievement of sustained environmental performance improvements through EMAS adoption is both contested and supported in the reviewed studies. On the other hand, improvements in the relationships with stakeholders arise as one of the most important intangible outcomes of the scheme. We conclude our review by advancing a systematic set of future research opportunities in this field.
\end{abstract}

Keywords: Eco-Management and Audit Scheme (EMAS); EMAS research themes; environmental management systems; comprehensive literature review; organisational environmental performance

\section{Introduction}

Over the past 20 years, organisations have been adapting to more demanding societal pressures and stringent environmental laws. Voluntary environmental policy instruments, such as Environmental Management Systems (EMS), have had a surge with the publication of standards and regulations, most notably ISO 14001 and the Eco-Management and Audit Scheme (EMAS), leading to the certification of an increasing number of organizational EMS. 
Particularly in the European context, EMAS has been playing an important role in the promotion of pollution prevention strategies, continuous improvement, and public disclosure of environmental performance in organisations. According to the European Commission (EC) [1], EMAS has been pivotal in fostering corporate social responsibility practices in firms, which made up an estimated $80 \%$ of over 4,600 organisations registered in EMAS by 2012.

EMAS was initially adopted by the European Union (EU) in 1993. In 1998, the EC asked for a review of EMAS, which was approved and published in 2001, under the denomination EMAS II. A new review was prepared between 2006 and 2009, and in 2010, EMAS III was enforced. In the first edition, the EMAS register was only open to industrial companies [2]. With EMAS II, a breakthrough in the integration with ISO 14001 was promoted and the requirements of this standard were adopted as the model for EMS implementation [3], along with other modifications to improve quality and acceptance by stakeholders [4,5]. From 2009 onwards, organisations from countries outside the European Union are also allowed to register in EMAS and small and medium Enterprises (SME) have special conditions supporting their registration.

Throughout this period, several authors have been developing research to address conceptual, procedural and performance issues in EMAS uptake. Although many studies and guidance documents have been developed to support EMAS implementation [6], and reviews on other EMS schemes such as ISO 14001 have been conducted [7], to our knowledge, there has not been a comprehensive account of the EMAS research themes addressed in the published scientific literature. Thus, in this paper, we draw from an extended pool of articles published over the past 20 years, focusing on an integrated critical analysis of the main trends in research topics underlying EMAS, taking stock of key findings and subsequently outlining opportunities for future research.

The methods applied to develop the literature review are described in the following section, as well as a broad characterisation of the selected sample of articles. The third section explores the key findings in EMAS research drawn from each of the major themes defined for the analysis. The fourth section comprises a discussion of the main lessons learned and a synthesis of future paths to bridge research gaps. Finally, the last chapter summarizes the main conclusions from our research.

\section{Methods and Delimitations of the Study}

This literature review was developed following four main steps (Figure 1). The search engine selected in the first step was Scopus abstract and citation database of peer-reviewed literature due to its extensive global coverage of journal and book titles that allowed for capturing a broad range of publications. The search combined two sets of keywords since the term "Eco-management and audit scheme," or the EMAS acronym alone, did not allow identifying several relevant publications. Search parameters were equal in both sets, such as document type (article or review) and search fields (title, abstract and keywords).

In the screening process (Step 2, Figure 1) all articles outside the time range, duplicated records and full papers not available through the subscription services of our host institution were excluded. Considering the languages we are proficient in or familiar with, we only selected from the search results the articles written in English, Portuguese and Spanish. Another screening criterion was the selection of all articles focusing on EMAS, which meant selecting all those having at least one reference to EMAS in the title, keywords or abstract.

The final set of documents used in the literature review was composed by 80 articles. Figure 2 shows the number of selected articles by year of publication, as well as the accumulated number of articles in the selected literature set. Fluctuations in the annual number of publications do not seem to have a relationship with the revisions of EMAS performed in 2001 and 2009. 


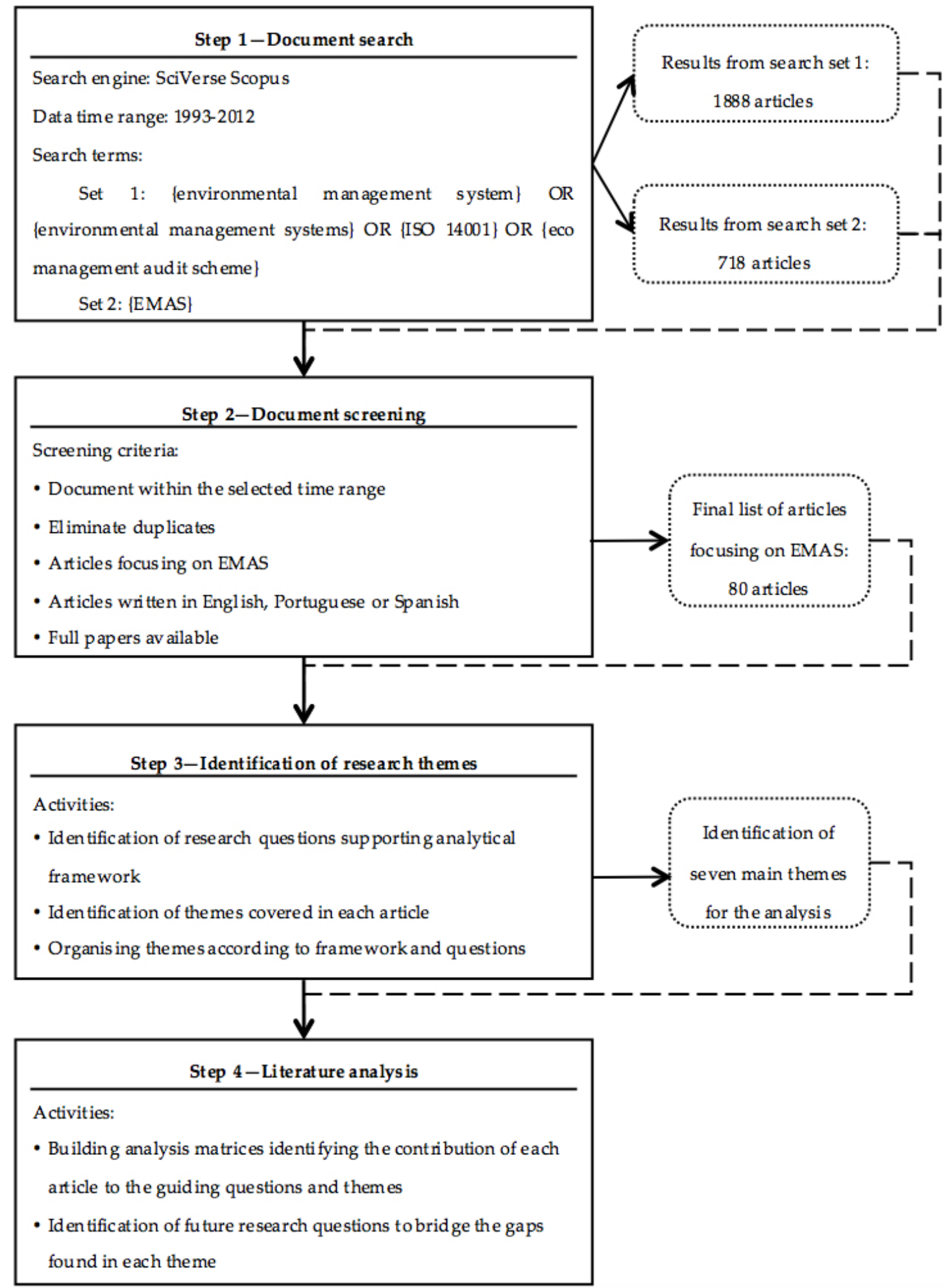

Figure 1. Schematic representation of steps and activities developed in the literature review process. 


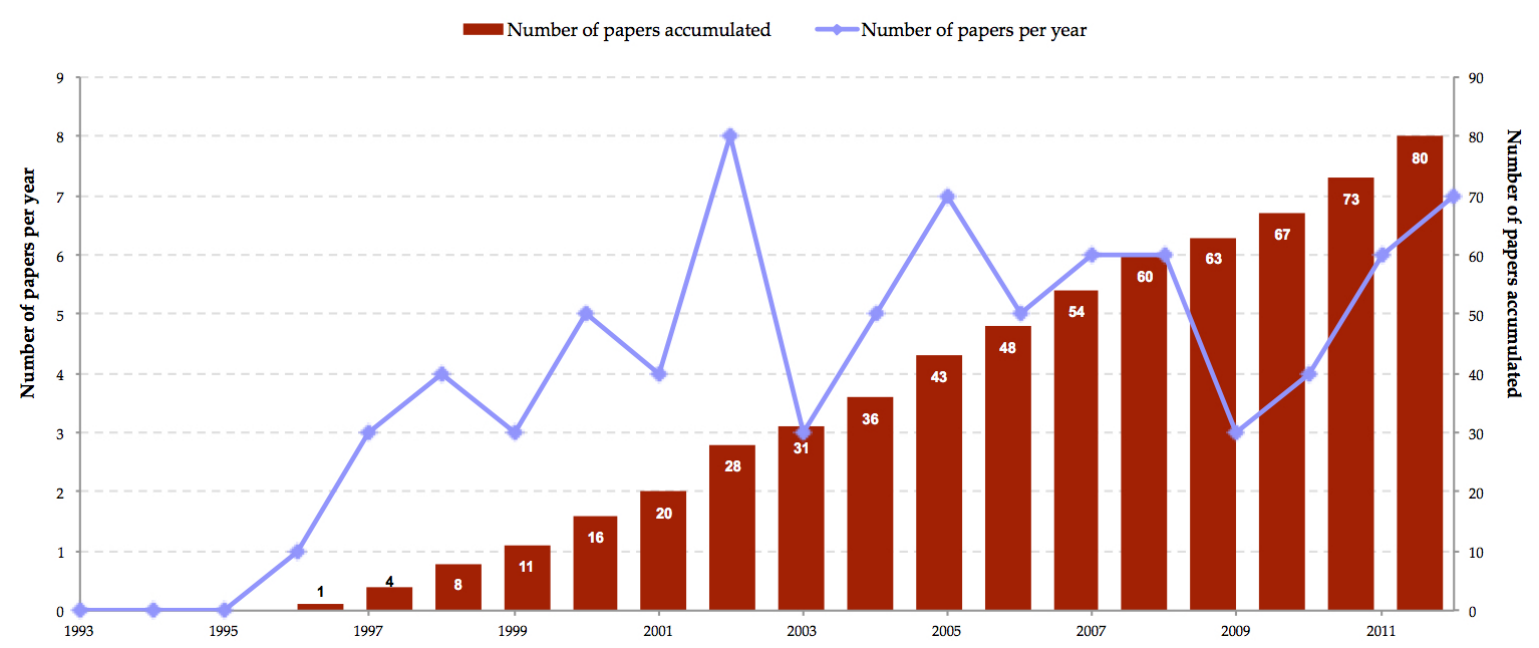

Figure 2. Evolution of the annual and cumulative number of articles in the reviewed set of publications.

As for the geographical distribution of case studies referred to in the reviewed set of articles, the European countries with the most references are Germany, Spain and Italy (Figure 3). It is worth noting that these countries correspond also to those with a higher number of registrations in EMAS, as of February 2015 [8].

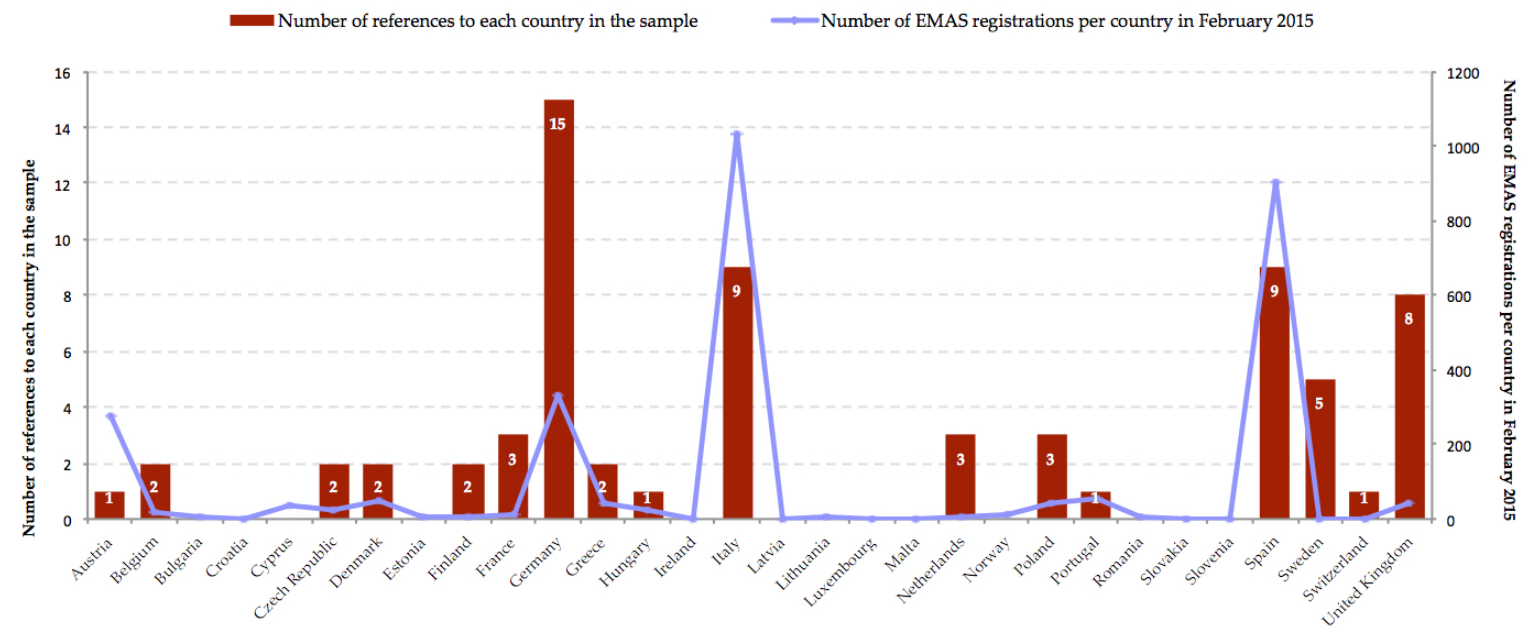

Figure 3. Number of country references in the selected literature versus EMAS-registered organisations per country [8].

To proceed to the in-depth analysis and guide the literature review (Step 3, Figure 1), a framework was developed around three broad categories of questions underpinning the main objectives of our study (Figure 4). In the light of the three guiding questions, the scope of each article was identified through the analysis of proposed goals, results and conclusions. The analysis of the scope of each article provided information to elaborate an extended list of topics covered by the literature included in the sample. Subsequently, similar topics were clustered into broader themes and then these themes were assigned to the research questions, depending on whether they were addressing issues related with EMAS goals (question 1), implementation (question 2) or outcomes and impacts (question 3). Thus, seven main themes emerged from the literature to answer the proposed initial questions of the study, as illustrated in Figure 4. 


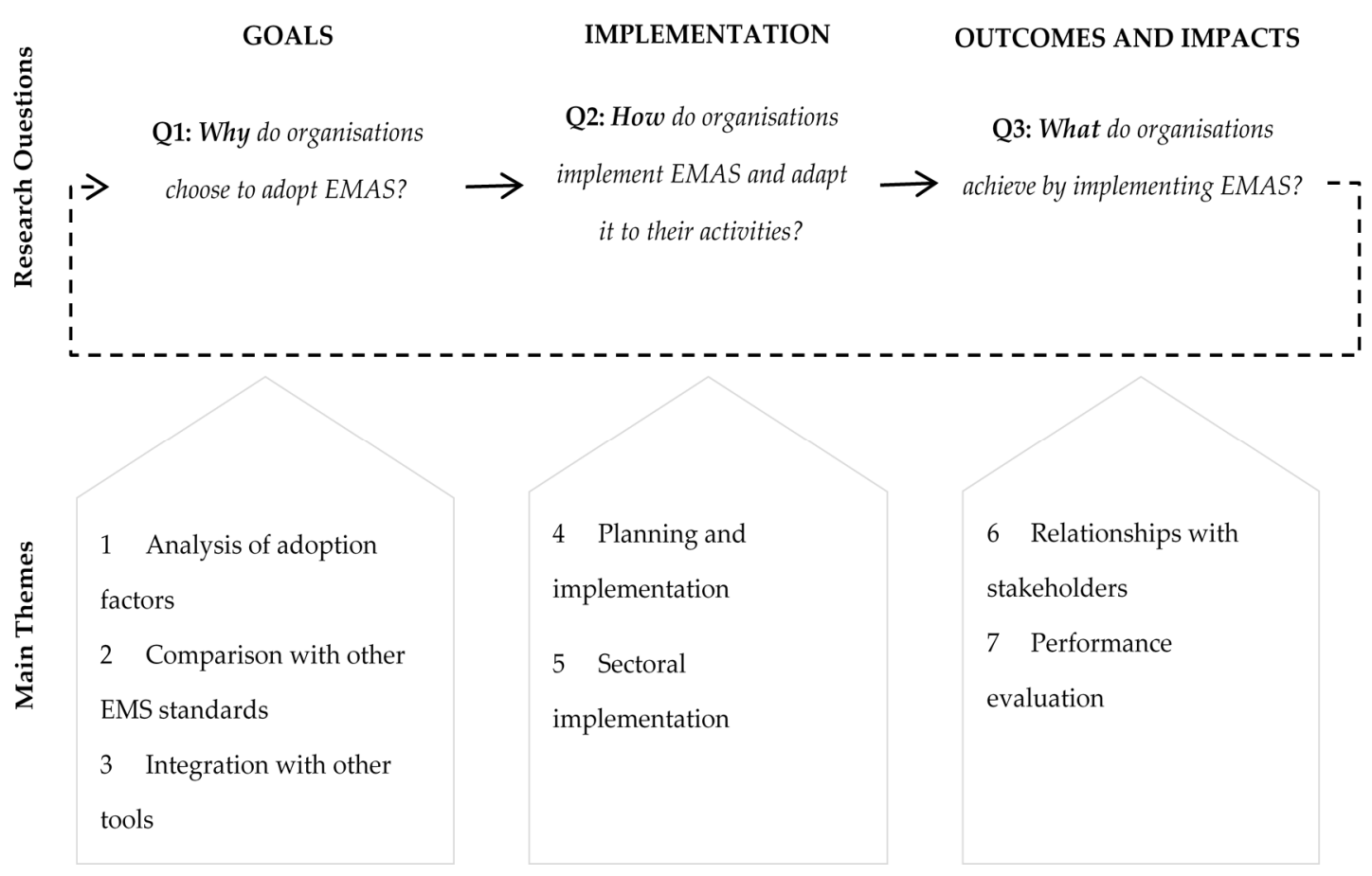

Figure 4. Questions and themes guiding the review of selected articles.

The first question is focused on the investigation of drivers and motivations leading organisations to adopt EMAS, which implies looking at adoption factors and comparing this instrument with similar tools fostering improvements in environmental performance. Literature in the sample provided three distinct sets of articles addressing themes connected with this question:

(1) "Analysis of adoption factors" is composed by studies focusing on the identification and analysis of factors influencing organisations' decision to adopt, implement and maintain the EMAS register;

(2) "Comparison with other EMS standards" gathers articles aiming to compare EMAS with other EMS standards, such as ISO 14001 and alternative EMS certification schemes;

(3) "Integration with other tools" addresses studies investigating the integration of EMAS with other environmental and sustainability management tools implemented in organisations.

The second question-"How do organisations implement EMAS and adapt it to their activities?"- aims at gaining an improved understanding of operational issues, such as specific EMAS implementation processes and tools, either due to the scheme's requirements or to particular conditions of organisations and their economic activity sectors. Two different sets of articles were found that dealt with this question, which were consequently classified as themes 4 and 5 :

(4) "Planning and implementation" gathers studies focusing on the EMAS implementation process, from the planning activities to more compliance with operational requirements of the scheme;

(5) "Sectoral implementation" includes articles oriented towards the study of approaches that adapt EMAS implementation to the specificities of different economic activity sectors.

The third question is concerned with the evaluation of outcomes and organisational impacts arising from EMAS implementation. In order to address this question, literature studies focusing mainly on the relationship with stakeholders in EMAS-registered organisations and on environmental performance issues were found. These were classified as themes 6 and 7, respectively:

(6) "Relationship with stakeholders" includes articles exploring EMAS influence on the relationships established between an organisation and its stakeholders; 
(7) "Performance evaluation" is a theme oriented toward the analysis of the relationship between the adoption of EMAS and the observed effects of the scheme in terms of organisational environmental performance.

The classification process provided data to draw a trend in the number of selected publications according to each research question. Figure 5 shows that articles focusing on why EMAS is adopted dominated the concerns of scholars during the initial ten years of implementation of the scheme. Interestingly, these trends suggest that as the scheme matured and became more widespread, the focus shifted towards the investigation of operational issues and evaluation of outcomes from EMAS implementation.

- Why do organisations choose to adopt EMAS?

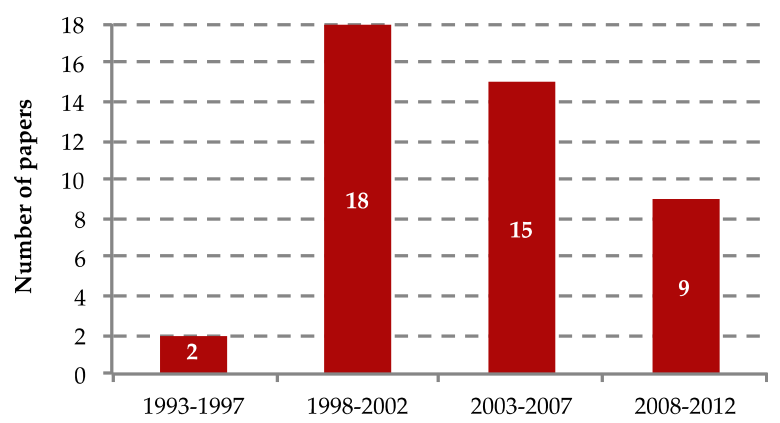

(a)

How do organisations implement EMAS and adapt it to their activities?

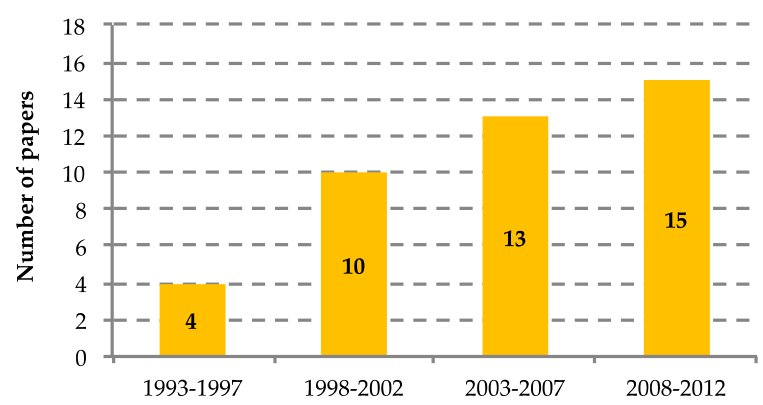

(b)

- What do organisations achieve by implementing EMAS?

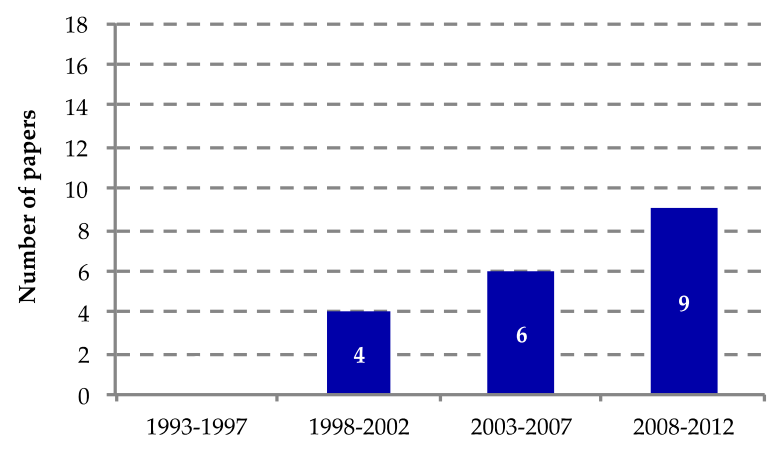

(c)

Figure 5. Number of selected publications most relevant to each guiding question: Why do organisations choose to adopt EMAS (a); how do organisations implement EMAS and adapt it to their activities (b); what do organisations achieve by implementing EMAS (c) in the time period between 1993 and 2012. 
The final step of the critical review process (Step 4, Figure 1) was supported by the construction of analysis matrices [9] that were built to identify the contributions of each article to each of the research themes. We have built a synthesis matrix to sort and categorize the information provided by each article. The columns across the top of the matrix were labelled with the publication's title and then the matrix rows were filled with the relevant arguments and ideas for each of the seven reviewed themes. The following sections provide a detailed analysis of the main results and insights elicited in our study, organized according to the selected questions and themes.

\section{Why do Organisations Choose to Adopt Eco-Management and Audit Schemes (EMAS)?}

\subsection{Analysis of Adoption Factors}

In 1998, less than 1\% of all industrial firms in the EU were registered in EMAS [10]. Thus, the analysis of the main factors influencing organisations in the decision to adopt EMAS became a relevant research goal. The approaches followed to identify EMAS' major adoption factors were found to be quite diverse and related to different stages of the EMS implementation cycle [11]. While Abeliotis [12] and Christiansen and Kardel [13] focused on national implementation conditions, Emilsson and Hjelm [14] and Priego et al. [15] developed their studies addressing issues related to specific sectors: local authorities and hotels. The studies with national scope also included the development of surveys aiming to discover the strengths, weaknesses, opportunities and threats surrounding the adoption of EMAS, often in comparison with other standards such as ISO 14001 [16,17]. Interviews with accreditation bodies, environmental verifiers and EMAS-registered sites in EU countries were conducted by Hillary [10] in the analysis of difficulties in implementing EMAS. Other studies are mainly focused on national environmental regulatory frameworks and their influence on the decision to implement EMAS [18,19].

The reviewed literature reveals that many organisations are driven to adopt EMAS with the expectation of achieving several benefits, such as ensuring legal compliance, promoting resource efficiency and cost reductions, lowering the risk of liabilities, improving relationships with stakeholders and their overall environmental performance $[11,12,14,16]$. Table 1 summarizes the several factors typically driving an organisation's decision to adopt EMAS, including internal and externally oriented motivations.

Table 1. Major motivations influencing the adoption of EMAS (adapted from [11-16,18,20-23]).

\begin{tabular}{lll}
\hline & - & Reduction of environmental impacts \\
& - & Improving environmental performance \\
& - & Promoting efficiency in the organisation \\
Internal reasons & - & Achieving cost reductions \\
& - & Making use of subsidies \\
& - Eoosting employees' motivation \\
& - & Other corporate conditions (e.g., corporate culture, financial conditions) \\
\hline & - Gaining competitive advantage \\
& - Addressing supply chain concerns \\
External reasons & - Improving image and marketing \\
& - Promoting market and trade relations \\
& - Addressing stakeholders' pressures \\
\hline
\end{tabular}

The combination of motivations behind EMAS implementation summarized in Table 1 may result in different organisational profiles. This was the focus of Priego et al. [15] who proposed a classification that includes four types of organisations: strategic, followers, greenwashers and laggers. The strategic and followers group include those organisations that are driven both by internal 
and external motivations, and are more likely to adopt EMAS to pursue its core and long-term objectives. On the other hand, greenwashers and laggers often fail to internalise the EMS in the overall organisational structure due to the predominance of short-term and marketing objectives, such as the improvement of the organisation's external image.

Interestingly, Bracke et al. [22] conducted a combined analysis, considering both internal and external adoption factors, concluding that large-sized organisations with good financial management and headquarters in a country in which the regulatory framework encourages EMAS implementation are more likely to pursue registration in the scheme. This result points to the importance of studying not only the motivations revealed by organisations implementing EMAS, but also the contextual supporting factors or barriers most likely to determine the success of EMAS implementation. Typical obstacles found in the literature include lack of alignment between top managers and the organisation's departments, costs of personnel training, need to update infrastructures and difficulties in implementing environmental management programs $[11,12,14]$. On the other hand, success factors for the implementation of EMAS include the strong commitment from top management, a clear definition and distribution of responsibilities, an adequate documentation of EMS, a pro-environmental corporate culture, continuous training and education and favourable regulatory frameworks $[11,14]$.

In particular, with respect to the influence of national environmental regulatory frameworks in EMAS adoption, Kollman and Prakash [24] found that the adoption of supranational regimes (such as, EMAS and ISO 14001) is strongly dependent on the institutional structures within the implementing countries. They proposed justifications for the higher adoption of EMAS in some countries (e.g., Germany) as a consequence of bringing forward the added value of this scheme through the regulatory relief measures offered, such as allowing one to waive duplication in environmental reporting and eliminating duplicated controls. This hypothesis was also supported by Kollman and Prakash [20] and Watzold et al. [25] who concluded that substantial regulatory relief is instrumental to raising EMAS adoption rate, especially when integrated into a comprehensive policy package of voluntary agreements. In addition, Glachant et al. [26] defended regulatory relief as the best solution to promote EMAS in comparison with subsidies. Finally, Perkins and Neumayer [21] revealed that EMAS is more popular in countries with a more flexible environmental regulatory framework that is less demanding on organisations. Thus, organisations would avoid traditional controlling mechanisms and its costs by taking the responsibility for environmental issues through EMAS implementation [27].

Other external factors that can considerably influence EMAS registration include supply chain bonds, banks and insurance companies [27]. While a pivotal organisation in a supply chain can demand its suppliers to comply with a set of requirements (e.g., EMAS registration), banks and insurance companies influence organisations by accepting better credit conditions and lower insurance premiums to EMAS-registered organisations. Levels of EMAS registration are also constrained by society's demand and public awareness of this management tool $[21,27]$, since the level of information also influences how environmental policies and regulations are interpreted [28].

\subsection{Comparison with Other Environmental Management System (EMS) Standards}

A wide range of standards and regulations are available to organisations regarding environmental management and other related issues. Most studies comparing EMAS with other standards are focused on EMAS and ISO 14001, since both involve the implementation of an EMS [29]. Despite initial competition between EMAS and ISO 14001, with the EMAS's first revision, the EC included ISO 14001 as the EMS model recommended by the European regulation. This revision reduced competition between both standards and increased the potential for complementarity, in which EMAS is considered a step closer towards environmental excellence in comparison to ISO 14001 [29-31]. Neugebauer [32] explored this issue in relation to the German automotive sector, wherein it was concluded that organisations with different levels of commitment to EMAS also have different perceptions of the relationship between EMAS and ISO 14001. Those strongly committed to EMAS perceive the scheme 
as an upgrade of ISO 14001. However, the author hints at the possibility that, in practice, EMAS and ISO 14001 are still somewhat competing standards, particularly for less committed organisations.

Furthermore, some literature explored how results obtained through EMAS adoption differ from outputs of ISO 14001 certification and, surprisingly, it seems there are fewer differences than expected. Although organisations might anticipate increased benefits with EMAS adoption, since this scheme is more stringent than ISO 14001, research results thus far showed that outputs were more influenced by environmental management strategies and corporate culture [32]. Costs associated with EMAS implementation should be higher in relation to ISO 14001 due to extra requirements, unless stakeholders are sensitive to a more demanding standard, and this reverts into benefits that offset those costs [29]. Therefore, ISO 14001 seems to be more attractive because of its lower implementation costs; however, EMAS can contribute to an improvement in the relationships between organisations and authorities [29,32]. Another important finding was that governments might influence organisations' choices in voluntary approaches through non-regulatory strategies, such as incentives and marketing. For example, Whitford and Tucker [31] found that EU countries have lower uptake rates of ISO 14001 certification than other countries, which may be compensated overall with the promotion of EMAS registrations.

The comparison between EMAS and simplified models of EMS implementation, such as those applied by small and medium enterprises (SME), has also surfaced recently in the literature. For instance, Ekoscan is a Spanish model for EMS certification applied in the Basque region and adapted to SME, which focuses on environmental performance. Despite facilitating the identification of environmental legislation with lower costs, authors found that Ekoscan organisations still regard incumbent standards (e.g., ISO 14001 and EMAS) as advantageous because of their social recognition at an international level and the positive connotations they provide [33].

\subsection{Integration with other Environmental and Sustainability Management Tools}

The integration of sustainability issues in organisations can be achieved through the implementation of several corporate social responsibility (CSR) tools. Ransburg and Vágási [34] studied a framework of standards focused on different dimensions of sustainability management and reporting. EMAS was considered in such a framework as the most demanding environmental management standard. However, since EMAS alone does not cover all relevant sustainability issues, these authors suggested integration of EMAS (or ISO 14001) with ISO 9001, AA1000, SA8000 and the Global Reporting Initiative (GRI).

In practice, EMAS is often considered together with a wider range of approaches supporting environmental and sustainability management processes. For example, Robèrt [35] developed The Natural Step (TNS) framework, which includes EMS along with a set of other environmental concepts and tools, such as Life Cycle Assessment (LCA), ecological footprint and factor X. In this context, EMS is considered the administrative tool needed to effectively implement the TNS framework at an operational level, while supporting sustainability principles and activities. Sustainability objectives should be included in the planning phase of EMS implementation and adequate metrics defined to monitor and evaluate the process. Here, EMS is envisioned as a tool cross-cutting all business sustainability decisions, connected with other concepts, such as total material flows, zero emissions, sustainable technology development, cleaner production and natural capitalism [36].

The compatibility between EMAS and product life cycle thinking methods was another prominent research topic in the reviewed literature. Continuous environmental performance improvements, environmental legislation compliance, monitoring activities and management of environmental aspects (e.g., namely resource consumption and waste) are some of EMAS requirements compatible with life cycle approaches [37]. This alignment is possible if the EMS is implemented following a value chain perspective, which was the case in Udo de Haes and De Snoo [38], where the utility of EMAS and product policies was analysed in the agricultural sector. They found that EMS certification has potential to enhance life cycle approaches in companies, for example through the publication of the 
environmental statement and references to certification in advertising. Despite this compatibility potential, EMAS should not be perceived as a replacement of product policy and LCA practices [37], but rather an instrument to ensure mitigation of environmental impacts [39]. The use of LCA in the assessment of environmental aspects' significance is further explored in Section 4.1.

Other models emerged along this line of research, namely the EMS model called Product-Oriented Environmental Management System (POEMS). POEMS focuses mainly on product eco-efficiency along the life cycle and includes the systematic application of Design for the Environment (DfE) practices [40]. Usually organisations develop POEMS based on PDCA (Plan, Do, Check, Act) cycles, which eases the integration with standards such as EMAS, ISO 14001 and ISO 9001; however, procedures must be constructed regarding Integrated Product Policy (IPP) principles, including: environmental communication, environmental improvement, product development, supplier and contractor selection, purchasing and production [40]. DfE enriches EMS by adding life cycle thinking to management, which contributes to a better identification of material and energy flows. On the other hand, EMS helps DfE initiatives to become more permanent, systematic and consistent. Thus, two key points of integration emerge: analysing environmental aspects in the product development process and including this process in the EMS. As a result, EMS gains a larger scope, and relationships with stakeholders in the supply chain can be fostered [40]. Improved stakeholder relationships are similarly highlighted by Ardente et al. [41], who focused on POEMS's applicability in SME. Supply chain partners are included in the process of identification of key environmental aspects of the production chain and in implementation of management measures.

The EMAS relationship with cleaner production practices is not obvious despite reference to "pollution prevention" in the EMAS text. Hillary and Thorsen [42] demonstrated that self-regulatory tools could promote cleaner production principles since the EMS structure encourages the adoption of cleaner production principles in innovation procedures and technological change. Also, EMS contributes to ensuring continuity of cleaner production projects, which otherwise would be abandoned after a particular project is concluded [43]. Furthermore, concerns about an excessive focus of EMS on procedural issues, rather than on environmental performance improvement, can be solved with the application of cleaner production practices [42,43]. Since these involve the identification and monitoring of gains in materials and energy flows in organisations, an EMS helps to structure and support activities to improve environmental performance and management of materials, energy, water, waste, and emissions. Thus, synergies between EMAS and cleaner production practices are closely connected and should be considered in tandem [43].

Rennings et al. [44] showed that EMAS also has a positive effect in environmental process innovation. The maturity of the EMS and the participation of specific departments, such as research and development (R\&D), in EMAS implementation increase its influence in environmental process innovations. These authors claim that environmental product innovation may also be positively influenced by learning processes developed during EMS implementation. The inverse relation is also supported, such as in the work published by Ziegler and Nogareda [45], in which the positive effect of environmental process innovations on the promotion of EMS certification was demonstrated.

Previous research also explored possible methods and programs aiming to encourage or improve EMAS implementation process by providing guidelines to specific environmental issues. Helby [46] studied the implementation of a Swedish labelling program called EKO-Energi that focuses on energy management in organisations. To be admitted into EKO-Energi, organisations must show real commitment with environmental management, since they are obliged to implement a set of energy management measures, including the definition of energy saving targets, the establishment of a plan concerning energy efficiency measures and the implementation of an environmental policy, and procurement procedures, among others. EKO-Energi includes support to EMAS or ISO 14001 firms interested in implementing a formal EMS, since these standards can reinforce measures taken under the program. Despite EKO-Energi's modest success as a label, it has shown to increase EMS focus on energy efficiency measures [46]. 
Another key issue found in the literature is the integration of EMAS with economic and financial tools, which is supported by studies focused on eco-efficiency, environmental accounting and economic performance. Economic performance relationships with EMS are not consensual, since mixed results have been reported in different studies. While Wysokinska and Witkowska [47] reported little impact of EMAS implementation in domestic sales and exports of products from EMAS-registered organisations in Poland, Rennings et al. [44] observed a positive linkage between effective EMAS implementation and economic performance. Andrews [48] stated that in spite of some successful cases of EMS implementation positively influencing economic performance, increased governmental incentives for voluntary approaches would be necessary in order to sustain these results. Furthermore, it was argued that global economic competition and financial restructuring can eliminate benefits obtained through EMS implementation and the consideration of long-term versus short-term investment criteria is not favourable to self-regulation approaches.

Research focusing on linkages between environmental accounting and EMAS has also been found, with some interesting results regarding possible synergies. Environmental accounting comprises the gathering, treatment and analysis of relevant data, such as material and energy flows, environmental costs and other quantifiable information which can be used to support decision-making in organisations [49]. Some characteristics of EMS, such as the continuous improvement rationale, stakeholders' involvement and organisational learning, provide arguments to support such positive effect [50]. For example, the development of environmental accounting procedures associated with EMAS implementation may be helpful for the elaboration of an environmental statement, thus combining information on eco-efficiency [51] and environmental management measures with their financial impacts [52].

\section{How do Organisations Implement EMAS and Adapt it to Their Activities?}

\subsection{Planning and Implementation}

While implementing EMS, organisations must define a procedure to identify and assess environmental aspects. EMAS does not define a specific methodology to perform this task. Hence, organisations are free to select or develop the method that better suits their activities, needs and structure. Due to the flexibility of this requirement, the methodologies applied in the identification and assessment of environmental aspects have become one of the most popular issues addressed in the literature.

Numerous methodologies have been presented, ranging from relatively straightforward procedures that follow EMAS guidelines [53] to more complex multi-method solutions [41,54-56]. Our review showed that two broad groups of approaches may be defined. The first group includes matrix-based methods using sets of significance assessment criteria. The second group of approaches includes the deployment of LCA-based methods. Table 2 summarizes the main contributions of the reviewed studies addressing the development of procedures for assessing the significance of environmental aspects of an EMS. 
Table 2. Methods for the identification and evaluation of significance of environmental aspects.

\begin{tabular}{|c|c|c|}
\hline Type of Approach & Overview of Case Studies & Contribution to Research on this Theme \\
\hline \multirow{3}{*}{$\begin{array}{l}\text { Traditional approaches: } \\
\text { Use of a set of } \\
\text { assessment criteria and } \\
\text { matrix to rank the } \\
\text { significance of } \\
\text { environmental aspects }\end{array}$} & $\begin{array}{l}\text { Zobel [57] described the main steps of traditional } \\
\text { approaches used to assess the significance of } \\
\text { environmental aspects. First, each environmental aspect is } \\
\text { scored on a numerical scale (defined by the organisation) } \\
\text { against each criterion. Second, an aggregated significance } \\
\text { score for each environmental aspect is calculated by } \\
\text { summing the scores attributed to each criterion (other } \\
\text { formulations may be applied in the final calculation of the } \\
\text { final significance score). A significance threshold is } \\
\text { established above which environmental aspects are } \\
\text { considered as significant. }\end{array}$ & $\begin{array}{l}\text { Authors describe the most common and } \\
\text { standardized approach to assess the } \\
\text { significance of environmental aspects based } \\
\text { on a sample of case studies in } \\
40 \text { Swedish organizations. }\end{array}$ \\
\hline & $\begin{array}{l}\text { Zobel and Burman [58] systematized the criteria deployed } \\
\text { in commonly used procedures for assessment of } \\
\text { significance of environmental aspects. These include: scale, } \\
\text { severity, probability of occurrence, permanence of the } \\
\text { impact, actual or potential regulatory exposure, difficulty } \\
\text { of changing the impact and stakeholders' concerns. }\end{array}$ & $\begin{array}{l}\text { Authors suggested a list of popular criteria } \\
\text { and areas for improvement in the procedures } \\
\text { for the assessment of the significance of } \\
\text { environmental aspects. }\end{array}$ \\
\hline & $\begin{array}{l}\text { In the method applied to local authorities by } \\
\text { Marazza et al. [59], aspects are assessed not only with } \\
\text { respect to environmental criteria (see row above for } \\
\text { examples) but also governance criteria. The governance } \\
\text { dimension refers to the level of responsibility and control } \\
\text { that the local authority has over the environmental aspects } \\
\text { identified in the EMS. }\end{array}$ & $\begin{array}{l}\text { This study showed the importance of } \\
\text { balancing strict environmental assessment } \\
\text { criteria with governance criteria, thus } \\
\text { considering also the effective capacity of } \\
\text { organizations to control significant aspects. }\end{array}$ \\
\hline \multirow{3}{*}{$\begin{array}{l}\text { LCA-based approaches: } \\
\text { Use of life-cycle } \\
\text { methods to assess the } \\
\text { significance of } \\
\text { environmental aspects }\end{array}$} & $\begin{array}{l}\text { Ardente et al. [41] applied LCA methods in a winery in } \\
\text { order to identify environmental aspects and evaluate their } \\
\text { significance. As a result, process phases with higher } \\
\text { environmental impact were signalled and the activities } \\
\text { contributing mostly to significant environmental impacts } \\
\text { were tracked. }\end{array}$ & $\begin{array}{l}\text { LCA methods supported the description of } \\
\text { the production process, identification of input } \\
\text { and output flows and a detailed analysis of } \\
\text { the environmental impacts. }\end{array}$ \\
\hline & $\begin{array}{l}\text { Gernuks et al. [54] studied the selection of the most } \\
\text { adequate LCA methods to support the identification of } \\
\text { environmental impacts and evaluate their significance in a } \\
\text { company from the automotive sector. The Ecopoint LCA } \\
\text { method [54] was suggested due to the simplicity of the } \\
\text { weighting procedure. }\end{array}$ & $\begin{array}{l}\text { The main perceived advantage of using LCA } \\
\text { was related to the systematic character of the } \\
\text { methodology, which also allowed creativity } \\
\text { among users. }\end{array}$ \\
\hline & $\begin{array}{l}\text { Liu et al. [60] developed an elaborated multi-method } \\
\text { framework integrating three categories of methods: risk } \\
\text { assessment, LCA and criterion-based methods. LCA is } \\
\text { applied in this context to support the identification of the } \\
\text { causal relation between an environmental aspect and } \\
\text { subsequently its pathway, receptor and impact. Risk } \\
\text { assessment methods were further deployed to evaluate the } \\
\text { probability of the impact and its risk. Finally, a } \\
\text { multi-criteria approach was used to identify significance } \\
\text { criteria and prioritise environmental aspects. }\end{array}$ & $\begin{array}{l}\text { This framework is based on solid theoretical } \\
\text { approaches to assess significance of } \\
\text { environmental aspects. Nevertheless, } \\
\text { organisations may find it difficult to apply } \\
\text { due to the data and expertise required to } \\
\text { accurately deploy these tools. }\end{array}$ \\
\hline
\end{tabular}

Environmental policy is one of the central elements of an EMS and some organisations use it as a starting point for implementation; however, most organisations formulate their environmental policy after the initial environmental review and the identification of significant environmental aspects [57]. According to this author, environmental policies developed after the initial environmental review tend to include more specific commitments and environmental objectives, while those developed as the first step of the EMS are usually more generic. Also, Liedtke et al. [61] presented a case study of EMAS implementation describing the environmental commitment of a small company and the steps towards certification. First, the company formulated an environmental policy, mainly focused on a product's life cycle, the regional focus of the firm, and energy supply. Second, an environmental audit was conducted to identify relevant material and energy flows, environmental problem areas and dematerialization potential. Finally, audit results were considered in the elaboration of environmental management programs, as well as compliance with environmental, economic and legal requirements.

Concerning the definition of EMS environmental indicators, findings suggest that before EMAS III, which advanced a set of core environmental indicators to be reported, a single standardised approach 
was not available. Such lack of a common indicator framework has hindered the comparison and benchmarking of environmental performance across registered organisations [62]. This issue will be further explored in Section 5.2.

The environmental statement is a distinctive feature of EMAS, which supports monitoring and external communication of organisational performance [63]. However, several authors observed lack of interest of stakeholders in relation to this communication tool, which might compromise its usefulness as a marketing instrument [10,64]. According to the EMAS, the reported information should include a general description of the organization, the environmental policy, the structure of the EMS, the most important environmental issues related to activities, products and services, environmental management programs and key performance indicators. Additionally, Herczeg [65] argued that in order to achieve successful communication, environmental statements must not only provide a credible account of such items, but also a comprehensive view of the organisations' environmental performance and its influence on profit and relationships with stakeholders.

\subsection{Sectoral Implementation}

Following EMAS III commitments, the EC has been developing EMAS reference documents and guidelines for specific sectors of economic activity. The elaboration of Sectoral Reference Documents (SRD) on best environmental management practices is a task being developed by the Institute for Prospective Technological Studies from the EC-Joint Research Centre (IPTS-JRC). These documents contain technical information describing the best environmental practices that organisations from a specific sector can apply to improve environmental performance, environmental indicators and benchmarks [66]. Considering the extensive work involved in the production of SRD, the EC established a group of priority sectors: retail trade, tourism, construction, public administration, agriculture (crop production and animal production), food and beverage manufacturing, car manufacturing, manufacture of electronic and electrical equipment, manufacture of fabricated metal products except machinery and equipment, waste management and telecommunications. These sectors were selected according to three main criteria that included the environmental impact of the sector in the EU, the sector's level of EMAS uptake and the potential of improvement in the value chain [66]. Furthermore, EU countries are also encouraged to develop their own sectoral studies and to develop sectoral guidelines for EMAS implementation [67].

The policy relevance of sectoral studies resonates with the attention devoted to this topic in the scientific literature. Among all sectors, local authorities are the most studied organisations in the set of reviewed articles, followed by ports and energy production utilities. Figure 6 depicts the distribution of the number of references in the sampled literature across different sectors of economic activity.

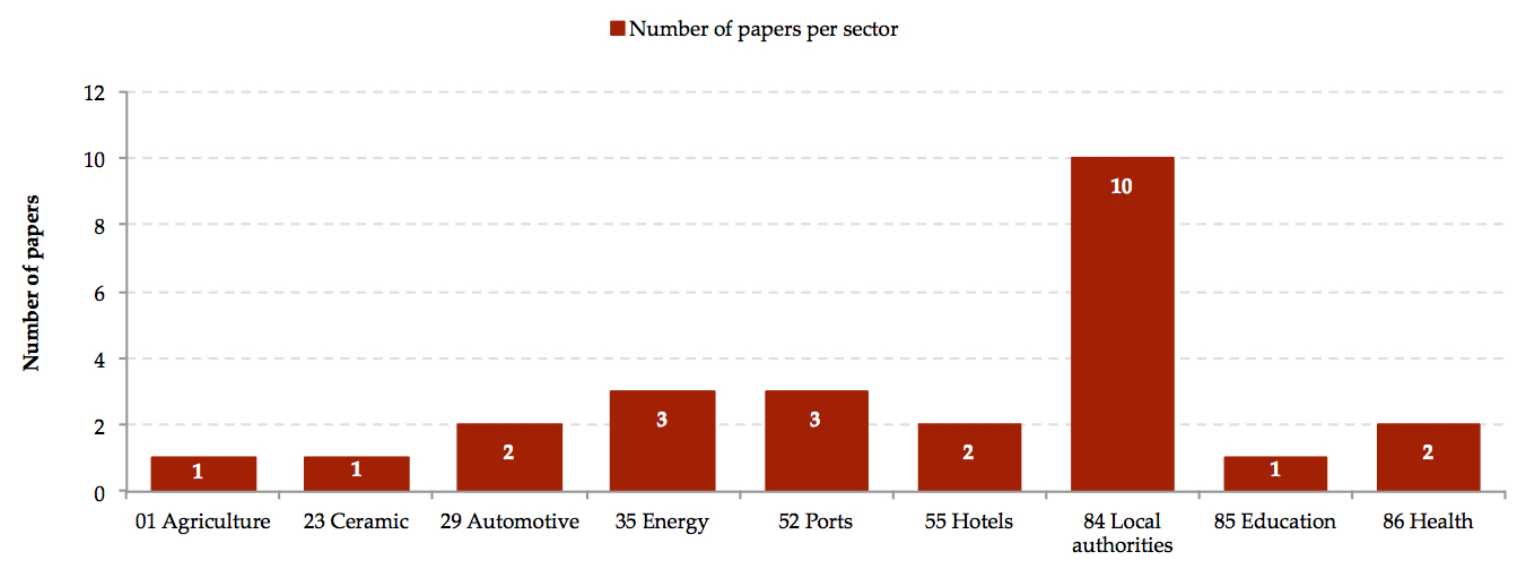

Figure 6. Number of articles referring to sectoral approaches, per activity sector. 
Ultimately, there are two broad approaches in the EMAS sector-oriented literature. In the first approach, sectoral applications are used to illustrate conceptual or theoretical analyses of EMS issues, although the sectoral perspective is not the central focus of the study. This was observed in several articles (described elsewhere in the other key themes presented in this paper) wherein sectoral case studies are used to demonstrate the practical implementation of proposed methods or tools. On the other hand, another trend was found, wherein authors do privilege the study of the applicability of EMAS to a given sector. Table 3 summarizes the sectoral-specific research topics addressed in the reviewed literature. In these studies, the main objectives usually include: i) improve understanding on the sectoral conditions for EMAS adoption, ii) provide stepwise implementation guidance to organisations; iii) propose adaptations in the general model of EMAS implementation, and iv) help organisations in a given sector to increase effectiveness in their EMS.

Table 3. Research topics addressed in literature related to specific sector applications.

\begin{tabular}{|c|c|c|}
\hline Sector/NACE Code & Research Topics Addressed & References \\
\hline Agriculture (NACE code 01) & $\begin{array}{l}\text { - } \quad \text { Application of environmental approaches in agriculture; } \\
\text { Integration of LCA and EMAS as tools for environmental } \\
\text { commitment in the value chain. }\end{array}$ & {$[38]$} \\
\hline Ceramic (NACE code 23) & - $\quad$ Advantages of EMAS implementation in the ceramics sector. & {$[68]$} \\
\hline Automotive (NACE code 29) & $\begin{array}{l}\text { - Development of a method for identification and assessment of } \\
\text { environmental aspects in the automotive sector; } \\
\text { - Influence of EMAS registration in the adoption of environmental } \\
\text { practices in organisations and the supply chain; } \\
\text { - } \quad \text { Relationship between the focal organisation and its suppliers. }\end{array}$ & {$[54,69]$} \\
\hline Energy (NACE code 35) & 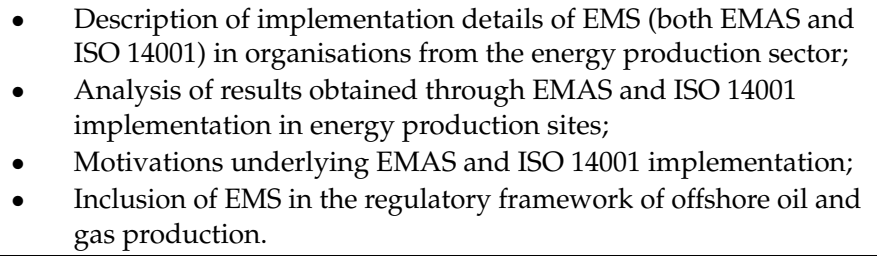 & {$[16,19,30]$} \\
\hline Ports (NACE code 52) & $\begin{array}{l}\text { - } \\
\text { - } \quad \text { performance in ports and discussion of its advantages; } \\
\text { Description of a system of environmental indicators adapted } \\
\text { to ports; } \\
\text { EMS implementation process and information about } \\
\text { environmental aspects in recreational ports. }\end{array}$ & {$[70-72]$} \\
\hline Hotels (NACE code 55) & 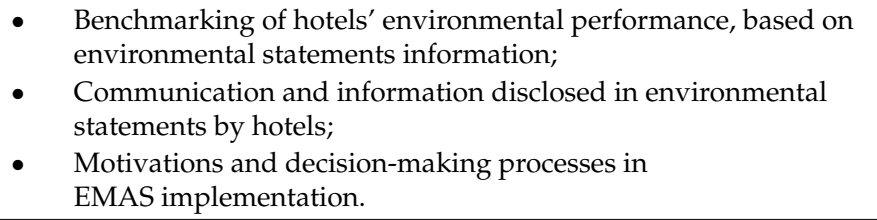 & {$[15,73]$} \\
\hline Local authorities (NACE code 84) & $\begin{array}{l}\text { - } \\
\text { Adoption factors of EMAS in local authorities, such as } \\
\text { - } \quad \text { Description of methods and approaches applied in local } \\
\text { - } \quad \text { Evthorities to achieve EMAS registration; } \\
\text { - } \quad \text { Identification and assessment of environmental aspects; } \\
\text { - } \quad \text { Definition of a core group of environmental indicators to } \\
\text { compare performance and support benchmarking. }\end{array}$ & $\begin{array}{c}{[5,14,53} \\
59,74-79]\end{array}$ \\
\hline Education (NACE code 85) & $\begin{array}{l}\text { - } \quad \text { Analysis of the role of EMAS on a university campus; } \\
\text { - } \quad \text { EMAS contribution to environmental education and awareness. }\end{array}$ & {$[80]$} \\
\hline Health (NACE code 86) & $\begin{array}{l}\text { - } \\
\text { - } \quad \text { Desplicability of EMAS in hospitals; } \\
\text { - } \\
\text { Analysis of adoption factors in this sector, such as benefits, } \\
\text { obstacles and costs. }\end{array}$ & {$[81,82]$} \\
\hline
\end{tabular}




\section{What do Organisations Achieve by Implementing EMAS?}

\subsection{Relationships with Stakeholders}

EMAS' contribution to strengthening relationships between organisations and stakeholders has, thus far, been seldom explored in the literature. However, some issues have been addressed, such as the potential of EMAS to improve stakeholders' involvement and participation, the relationships between organisations and specific stakeholders and the influence of stakeholders in EMAS diffusion. Typically, EMAS implementation is associated with an increase of an organisation's credibility among its stakeholders, partially due to the publication of a validated environmental statement $[63,83]$. This requirement increases transparency by reporting detailed information about operations and management practices. Thus, stakeholders' trust in EMAS organizations also tends to increase [83]. However, according to Honkasalo [63], interested parties tend to focus their attention on specific targets, activities and accomplishments rather than overall goals. In order to improve efficiency of communication, understanding stakeholders' demands and interests regarding reported information is crucial. Furthermore, increasing EMAS visibility and certifiers' credibility are two additional factors influencing stakeholders' perception on the usefulness of the scheme [20,29].

From an organizational perspective, EMAS stands out as a privileged tool to communicate with stakeholders, either internally or externally. Borsese et al. [84] explored this topic and concluded that a successful EMS implementation requires active involvement of employees in the process. Once they are involved, the resistance to include EMS activities in their daily routine diminishes and the availability to cooperate in the implementation process increases. Environmental training is one of the most common and successful practices applied to motivate employees and integrate them in the EMS loop. Nevertheless, other communication tools are also typically used, such as leaflets, memos and person-to-person motivation [84]. Some authors proposed exploring the evolution of employees' perceptions regarding social and environmental standards, reporting systems and labelling schemes [11,50]. On the topic of internal stakeholder involvement, Ferreira et al. [80] described a case study where EMAS was applied in a university, not only as a management tool, but also as an educational example for students. The EMS allowed environmental engineering students to participate in practical activities, which improved the quality of their training. Students, faculty and other staff were also invited to contribute to the process, which enriched the EMS, raised environmental awareness from students enrolled in other scientific areas and complemented their education, by teaching communication skills and how to engage stakeholders.

With respect to external communication, the definition of formal communication channels has been defended to increase consumers' satisfaction and confidence in the organisation. Stakeholders contribute actively to EMS improvements by providing recommendations to the organisation and most managers will opt to develop actions in accordance with their suggestions [84]. The relationship with suppliers and environmental requirements observed across the supply has been addressed by González et al. [69] who supported the hypothesis that organisations with an EMS are more demanding toward their suppliers in terms of adoption of environmental practices. Organisation size also influences the capacity to pressure suppliers, since larger organisations tend to have more leverage and resources, and thus are more successful in demanding further environmental commitment from their stakeholders [20,69]. Lannelongue and González-Benito [85] debated the ability of an EMS to discriminate between stakeholder groups with respect to the intensity of their collaboration relationships. For example, a certified EMS seems to block away pressures from secondary/distant stakeholders while bringing the organization closer to their shareholders, employees and local communities.

\subsection{Performance Evaluation}

Literature on environmental performance evaluation focuses on two main questions: how to evaluate environmental performance in the context of an EMS and whether EMAS implementation 
influences environmental performance in organisations. Most research under this theme is based on environmental indicators and reporting practices. Some of these studies advance frameworks or metrics to support organisations in the process of monitoring and reporting environmental performance.

Hřebíček et al. [86] studied key performance indicators to incorporate in organisations' environmental reports. The resulting framework included indicators on efficiency of material consumption, energy efficiency, water management, waste management, biodiversity, airborne emissions, products and services, compliance with legislation, economic benefits of environmental conservation activities and environmental efficiency of business activities. Thus, according to this framework, organisations with EMAS or ISO 14001 can report standardised environmental information, which allows the evaluation and comparison of environmental performance within sectors.

A similar study was presented by Jasch [87] wherein ISO 14031 was applied as the basis to formulate a possible indicator framework for breweries. The effort to develop environmental indicator benchmarks adapted to sector-specific activities was justified by the requirement that organisations should register in an EMAS under a given NACE code. The author argues that achieving standardisation would allow the evaluation and accounting of environmental status of each country and/or sector. Also, applying ISO 14031 as the cornerstone in the construction of the framework guarantees quality, since the standard defines a set of principles to guide the development of environmental indicators, such as comparability, balance, continuity, frequency, comprehensibility and target orientation.

Olsthoorn et al. [62] also focused on the quality of indicator formulation, presenting a possible approach to define and implement a set of environmental indicators adapted to organisational activities. This procedure includes the following four steps: (i) collection of data from physical, economical, business, management and environmental indicators; (ii) establishment of a database with environmental indicators' information; (iii) integration of environmental information into an indicator which expresses environmental impacts; (iv) combination of those data into environmental performance indicators. Such management performance indicators were perceived to enrich the quality of the environmental performance information reported. These authors concluded that organising indicators by environmental subject allows organisations to monitor and evaluate environmental performance by product or process.

Focusing on the possibility of using environmental indicators to support benchmarking processes, Mazzi et al. [79] used environmental indicators sets for local authorities. They found that existing data did not allow comparison between organisations, nor did it support environmental benchmarking, since they were unevenly distributed between environmental subjects and between direct and indirect aspects. In some cases, indicators failed to measure what they were supposed to and other times they were not properly designed. Another obstacle to the comparison of local authorities' environmental performance through indicators is its diversity. Local authorities thus implement different indicators to monitor the same environmental aspects, which prevented possible comparisons. As a result, the authors reinforced the need of standardisation of indicator sets within organisations from the same sector. Petrosillo et al. [53] aimed to fill this gap, considering EMAS III requirements on core indicator sets. They found that local authorities did not always report all environmental indicators described in EMAS III, such as energy from renewable resources, built-up areas and production of hazardous wastes. Also, environmental indicators selected were mostly operational performance indicators, rather than management performance indicators and were more focused on direct environmental aspects. A list of 13 environmental indicators was then proposed, which covered EMAS requirements and the diversity of environmental issues in local authorities, while allowing the analysis of performance trends and inter-organisational comparisons.

In line with a sectoral approach to indicator development, Priego and Palacios [73] presented a study on how some organisational factors could influence information reported in EMAS' environmental statements of hotels. Once again, information disclosed did not allow a comparison between organisations from the same sector due to differences in indicator selection or even measuring 
units. In contrast with the initial hypothesis, it seemed that organisations' size, type of tourism, ownership and years of environmental certification did not affect the information reported, except in the case of independent hotels that disclosed more information about environmental operational indicators than chain-owned hotels.

EMS models, such as ISO 14001 and EMAS, do not define environmental performance minimum levels that organisations must accomplish to obtain certification or registration. Thus, achieving EMAS registration does not guarantee per se that the organisation reaches an excellent level of environmental performance. It rather ensures that organisations are committed to assuring continuous environmental improvements [88].

Research findings point to the fact that environmental performance upgrades due to EMS adoption are dependent upon the extent of EMS integration in the structure of the organisation, rather than the maturity of the management system. Pérez et al. [50] defined three levels of embeddedness of the EMS in organisations: the first included organisations which needed to assure environmental performance improvement in the long run; the second level is characterised by a higher influence of environmental issues in the organisational structures and strategies; finally, the third level includes development of intangible assets that guarantee full integration of the EMS over time in the organization. From this perspective, linkage and synergies between intangible assets arising from EMS adoption (e.g., employees' awareness and environmental knowledge) lead to a higher level of embeddedness in the organisation, which further contributes to an improvement in environmental performance. On the other hand, Iraldo et al. [89] argued that EMS implementation has a positive effect in resource productivity, market performance and intangible assets. This reinforces the idea that a well-designed EMS, effectively integrated into the organisational structure, is capable of increasing competitiveness. Also, EMAS enhances environmental planning and innovation capacities, which in turn lead to performance improvements, although certification alone is not a sufficient condition for achieving those goals.

An empirical analysis of EMAS influence on organisational environmental performance was developed by Daddi et al. [90]. The evaluation of environmental performance before and after EMAS implementation allowed these authors to conclude that, in general, organisations tend to improve, or at least not worsen, their environmental performance with EMAS registration. Despite this positive trend, some exceptions were identified considering specific environmental aspects, such as energy consumption. Also, EMAS implementation may not constitute a turning point in organisations' environmental commitment, but instead a natural step towards an improved environmental performance. Another important finding in this study was the possibility of EMAS achieving environmental performance improvements in the short term. Significant improvements may be obtained through the implementation of measures with moderated managerial, organisational and economic effort in the first years of EMAS implementation- "the low hanging fruit." Though it is not a guarantee of continuous improvement in the following years, since further improvements would represent a greater marginal effort, it possibly contributes to increasing organisations' motivation and commitment [90].

\section{Synthesis of Lessons Learned and Further Research}

With respect to the first research question presented in this study-“Why do organisations choose to adopt EMAS?"- our review showed that many factors might influence organisations in this decision, and there does not seem to be a single dominant factor (Table 4). Several authors have explored the motivations, corporate conditions, success factors, obstacles, benefits and costs reported by registered organisations, thus the underlying factors are quite extensive. While some of these drivers are internal (e.g., increasing operational efficiency and costs savings), others are external to organisations (e.g., national environmental regulatory frameworks, supply chain requirements, bank loans, insurance policies, societal demands and public awareness). Research opportunities arise with 
respect to further exploring the role that some of these factors might play in particular regulatory contexts and corporate conditions.

Table 4. Main findings on "why do organisations choose to adopt EMAS?" and recommended further research.

\begin{tabular}{|c|c|c|}
\hline Themes & Main Findings & Further Research \\
\hline $\begin{array}{c}\text { Analysis of } \\
\text { adoption factors }\end{array}$ & $\begin{array}{l}\text { - A wide range of factors influence organisations } \\
\text { in their decision to implement EMAS, such as } \\
\text { motivations, factors of success, obstacles, } \\
\text { expected benefits and costs. } \\
\text { - Organisations' characteristics and corporate } \\
\text { conditions also affect EMAS adoption. } \\
\text { Different patterns of variation in EMAS } \\
\text { adoption across countries, depending on the } \\
\text { flexibility of regulatory frameworks and } \\
\text { incentives adoption (e.g., subsidies and } \\
\text { regulatory relief). }\end{array}$ & $\begin{array}{l}\text { - Investigation of the government's role in EMAS } \\
\text { registration, key factors in policy content that } \\
\text { contribute to EMS implementation and analysis of the } \\
\text { influence of regulatory tools in the internalisation of } \\
\text { long-term EMS benefits. } \\
\text { - Deepen the study on institutional analysis of EMS to } \\
\text { better understand which actors, institutions and policy } \\
\text { implementation conditions are relevant for } \\
\text { EMS adoption. } \\
\text { Explore the relationship between some factors external } \\
\text { to organisations (e.g., supply chain, imports and } \\
\text { exports) in the implementation of environmental } \\
\text { management practices. } \\
\text { How do different adoption factors influence } \\
\text { effectiveness of environmental practices? } \\
\text { Analysis of corporate conditions in which EMS has to } \\
\text { be integrated and how they influence the adoption of } \\
\text { environmental practices. } \\
\text { Verification of the hypothesis that standards aiming } \\
\text { absolute improvement (such as EMAS) are motivated } \\
\text { by internal factors; while other standards (such as ISO } \\
\text { 14001) are driven by external factors. }\end{array}$ \\
\hline $\begin{array}{c}\text { Comparison with } \\
\text { other standards }\end{array}$ & $\begin{array}{l}\text { - The relationship between ISO } 14001 \text { and EMAS } \\
\text { is the most studied, regarding its definition as } \\
\text { substitution or complementarity. } \\
\text { - Synergies with other corporate and social } \\
\text { responsibility tools are explored, highlighting } \\
\text { EMAS potential as a strategic tool in the } \\
\text { management of the environmental dimension } \\
\text { of CSR and sustainability. } \\
\text { Analysis of simplified EMS models, as } \\
\text { alternative options to small organisations or a } \\
\text { step towards EMAS implementation. }\end{array}$ & 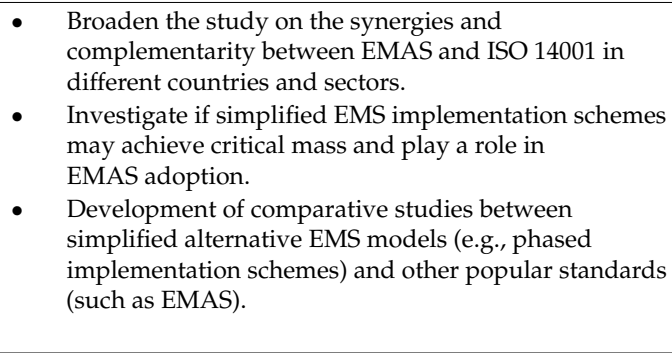 \\
\hline $\begin{array}{l}\text { Integration with } \\
\text { other } \\
\text { environmental and } \\
\text { sustainability tools }\end{array}$ & $\begin{array}{l}\text { - Integration with life cycle tools is a popular } \\
\text { practice, resulting on alternative models such as } \\
\text { POEMS (Product-Oriented Environmental } \\
\text { Management Systems). } \\
\text { EMAS supports environmental innovation in } \\
\text { processes and products. } \\
\text { - Authors explore the combination with } \\
\text { economic and financial tools and concepts, such } \\
\text { as environmental accounting and eco-efficiency } \\
\text { as a viable path. } \\
\text { Customised EMS implementation methods and } \\
\text { programs can precede or enhance } \\
\text { EMAS implementation. }\end{array}$ & $\begin{array}{l}\text { - What is the level of integration between EMS and } \\
\text { - } \quad \text { Evality, health and safety management systems? } \\
\text { between product-oriented certification schemes and } \\
\text { organizational EMS. } \\
\text { - } \quad \text { Study the degree of influence of EMS in DfE practices. } \\
\text { - How may EMAS influence the adoption of } \\
\text { technological environmental innovations? } \\
\text { Identification of environmental accounting practices } \\
\text { and how they can contribute to environmental } \\
\text { performance improvement. }\end{array}$ \\
\hline
\end{tabular}

Our review also showed that the relationship between EMAS and other standards, namely ISO 14001 , has been extensively studied. However, despite recent efforts to emphasise the compatibility of schemes, results indicate an association that often oscillates between substitution and complementarity, which calls for further research on this topic, particularly in the light of the recent ISO 14001 revision [91]. Additionally, investigation of the role of simplified or phased schemes is still at an inception stage, and it is not evident whether these approaches will be able to gain critical mass and constitute a springboard towards EMAS registration.

Possible integration of EMS with other sustainability and environmental assessment tools is also a research area worth exploring. Life cycle assessment, design for the environment and cleaner production are often suggested to be integrated with EMAS, leading to the development of comprehensive systems such as POEMS (Product-Oriented Environmental Management System). Other new methodologies (e.g., EKO-Energi) are presented in the literature as tools that can enhance 
EMAS implementation. Synergies with process and product innovation and economic tools, such as environmental accountability and eco-efficiency, have been less studied and are suggested as avenues for future research.

Concerning the second research question- "How do organisations implement EMAS and adapt it to their activities?" - we found that the implementation of specific EMAS requirements is well documented in the reviewed literature (Table 5). Several authors have focused on the development of methods to identify and assess environmental aspects and understand how environmental policy guides organisations through the EMAS implementation cycle. Research opportunities arise with respect to the definition of standardised environmental performance indicators and elaboration of environmental statements, fostering improvements in the quality and comparability of the information provided in the context of the EMS.

Table 5. Main findings on "How do organisations implement EMAS and adapt it to their activities?" and recommended further research.

\begin{tabular}{|c|c|c|}
\hline Themes & Main Findings & Further Research \\
\hline $\begin{array}{l}\text { Planning and } \\
\text { implementation }\end{array}$ & $\begin{array}{l}\text { Diverse approaches and methodologies to } \\
\text { identify and assess the significance of } \\
\text { environmental aspects are presented ranging } \\
\text { from simple methods to life cycle assessment. } \\
\text { - Organisational environmental policies are the } \\
\text { first step in EMAS implementation and guide } \\
\text { all the process. } \\
\text { - Standardisation is required in environmental } \\
\text { indicators' definition, in order to allow } \\
\text { comparison between organisations. } \\
\text { Environmental statements are pointed as } \\
\text { possible communication and monitoring tools } \\
\text { to organisations. }\end{array}$ & $\begin{array}{l}\text { - Extending the comparison of LCA based on } \\
\text { conventional approaches for evaluating the } \\
\text { significance of EMS environmental aspects. } \\
\text { Analysis of environmental statement's elaboration } \\
\text { process, including sources of guidance (e.g., } \\
\text { competitors' environmental reports), collection of } \\
\text { information and environmental indicators selection. } \\
\text { Further research on the quality and usefulness of } \\
\text { environmental statements, as a tool for } \\
\text { communicating environmental performance. }\end{array}$ \\
\hline $\begin{array}{c}\text { Sectoral } \\
\text { implementation }\end{array}$ & $\begin{array}{l}\text { - Studies focus on EMAS applicability to a } \\
\text { specific sector of economic activity (e.g., local } \\
\text { authorities) and provide guidance. } \\
\text { - Sectoral approaches are often used as a method } \\
\text { to define boundaries in studies. }\end{array}$ & $\begin{array}{l}\text { - Expand the analysis on the influence of EMAS } \\
\text { registration in the implementation of complementary } \\
\text { environmental practices to a larger set of countries, } \\
\text { sectors, environmental regulatory frameworks and } \\
\text { time periods. } \\
\text { Determine the usefulness of EMS in public sector } \\
\text { organisations, both at central and local levels and } \\
\text { formulation of key environmental indicator sets to } \\
\text { support and guide the evaluation and report of } \\
\text { environmental performance in public administration, } \\
\text { mainly regarding indirect environmental aspects. } \\
\text { Analysis of the application of environmental } \\
\text { performance indicators in benchmarking for different } \\
\text { sectors, building upon the benchmarks of excellence } \\
\text { provided in the SRD developed by IPTS-JRC. }\end{array}$ \\
\hline
\end{tabular}

The study of sectoral approaches for EMS implementation is a very relevant theme focusing on methods for customising the implementation of EMAS requirements to a given sector and guiding organisations in the adaptation of EMAS to their activities. Among economic activity sectors, local authorities, ports and energy production utilities are the ones most studied in the reviewed literature. Considering the on-going development of the benchmarks of excellence and Sectoral Reference Documents within the scope of EMAS III, this theme is a promising field for future research.

Finally, regarding our third research question- "What do organisations achieve by implementing EMAS?"-we found that there are two main streams underlying this research theme: studying the conditions for achieving continuous environmental performance improvements and the promotion of active stakeholders' participation. Although they are presented as key outcomes from EMAS implementation, the influence on stakeholders' relationships with registered organisations is scarcely studied and there is still no consensus about the positive effect of EMAS on environmental performance (Table 6). 
Table 6. Main findings on "What do organisations achieve by implementing EMAS?" and recommended further research.

\begin{tabular}{|c|c|c|}
\hline Themes & Main Findings & Further Research \\
\hline $\begin{array}{l}\text { Relationships } \\
\text { with stakeholders }\end{array}$ & 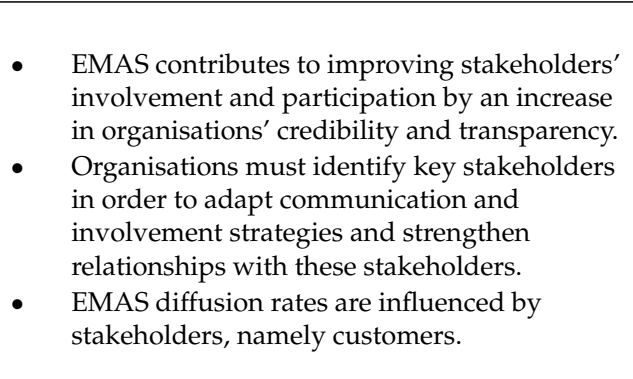 & 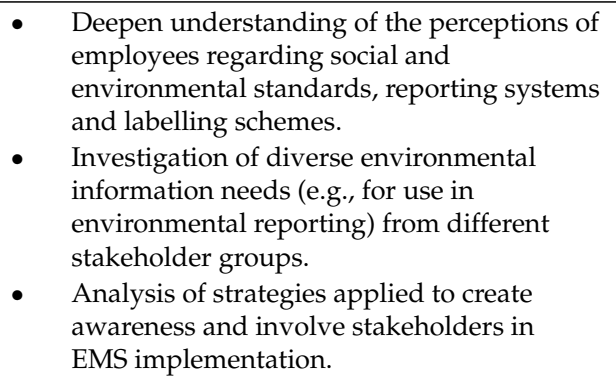 \\
\hline $\begin{array}{l}\text { Performance } \\
\text { evaluation }\end{array}$ & $\begin{array}{l}\text { - The most popular approach to environmental } \\
\text { performance evaluation in the literature is } \\
\text { environmental indicators, despite the variety } \\
\text { of development methodologies } \\
\text { and procedures. } \\
\text { Notwithstanding controversial results, EMAS } \\
\text { seems to have a positive effect on } \\
\text { organisations, at least in the development of } \\
\text { intangible assets and relying on the level of } \\
\text { maturity and integration of the EMS. }\end{array}$ & 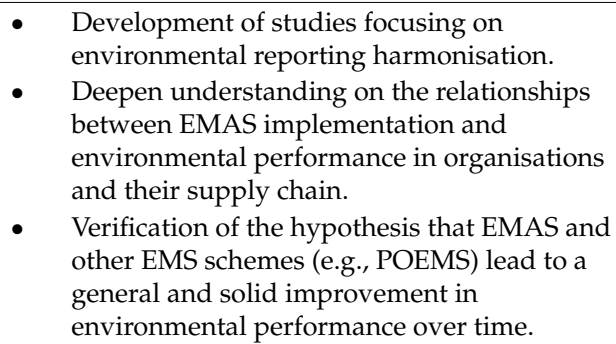 \\
\hline
\end{tabular}

EMAS implementation is widely regarded as a credibility and transparency driver, leading to an increase in stakeholders' trust. Despite research gaps underlining the need to advance processes of classification and prioritisation of stakeholders, as well as identifying their specific demands for information, EMAS is "by design" a vehicle for improving communication on environmental issues. The potential of some stakeholders (e.g., employees, customers and supply chain organisations) to improve EMAS implementation is highlighted in literature, as well as the influence of customers in EMAS diffusion rates.

Environmental performance improvement is the ultimate goal of EMAS; however, the presented state-of-the-art showed that there is still a lack of evidence on the direction of this relationship under different corporate conditions. Studies thus far have not identified a clear direct linkage between EMAS implementation and improvements in environmental performance, in spite of some authors supporting this hypothesis. Nevertheless, EMAS seems to produce a positive influence in the overall organisational performance, since it favours the development of intangible assets, such as external reputation and employees' motivation. Further research is suggested on methods to evaluate performance, complementing recent proposals for the standardisation of key environmental performance indicators and sets of benchmarks of excellence targeting a specific sector.

\section{Conclusions}

EMAS is an environmental management instrument created by the EC in 1993, which focuses on improvement of organisational performance. Since then, many research studies attempted to answer three broad questions concerning EMAS: (i) Why do organisations choose to adopt EMAS? (ii) How do organisations implement EMAS and adapt it to their activities? (iii) What do organisations achieve by implementing EMAS? In order to develop a comprehensive review of available research results, a sample of 80 papers focusing on EMAS was analysed in terms of major thematic issues related to EMAS implementation. When explaining why organisations choose EMAS, "analysis of adoption factors" and "integration with other environmental and sustainability tools" appear to be topics thoroughly debated in literature. However, authors suggested opportunities for further research, such as the relationship between environmental regulatory frameworks and EMAS uptake and the development of more studies concerning the "comparison with other standards" theme. 
When describing how organisations implement EMAS, "planning and implementation" and "sectoral implementation" themes were also found to be extensively documented and the latter is often addressed in complement with other topics. On the other hand, themes related to what can be achieved through EMAS adoption are less explored and more controversial. Following our review, several suggestions were advanced to explore the topic of "relationships with stakeholders" due to the scarcity of literature related to this theme. With respect to "performance evaluation," it was concluded that this theme has been gathering increasing interest; however, studies to date fail to give consistent results on the analysis of the relationship between EMAS implementation and environmental performance improvements.

The analysis of literature through the lens of the proposed framework and research questions provided an insight into the main issues extensively explored in the past, and those that, to our knowledge, have not been yet fully addressed. From the main lessons presented we propose the identification of opportunities for further research, which may bring support for EMAS continuous improvement as an environmental management instrument that should be well adapted to organisations evolving needs and realities.

Acknowledgments: CENSE is supported by the Portuguese Foundation for Science and Technology through $\mathrm{UID} / \mathrm{AMB} / 04085 / 2013$.

Author Contributions: Authors jointly defined the methodology, delimitations of the study and research themes. The first author conducted the elaboration of the analysis matrices and led the writing of findings, under the supervision of the second author. Both authors contributed to the critical review of EMAS research themes, having written, read and approved the final manuscript.

Conflicts of Interest: The authors declare no conflict of interest.

\section{Abbreviations}

The following abbreviations are used in this manuscript:

CSR Corporate social responsibility

EMAS Eco-management and audit scheme

EMS Environmental management system

LCA Life cycle assessment

SRD Sectoral reference documents

\section{References}

1. European Commission. Communication from the Commission to the European Parliament, the Council, the European Economic and Social Committee and the Committee of the Regions: A Renewed EU Strategy 2011-2014 for Corporate Social Responsibility. 2011. Available online: http://eur-lex.europa.eu/legalcontent/EN/TXT/?uri=celex\%3A52011DC0681 (accessed on 11 November 2015).

2. European Economic Community. Council Regulation (EEC) No 1836/93 of 29 June 1993 allowing voluntary participation by companies in the industrial sector in a Community eco-management and audit scheme. 1993. Available online: http://eur-lex.europa.eu/legal-content/EN/TXT/PDF/?uri=CELEX: 31993R1836\&from=EN (accessed on 11 November 2015).

3. Webb, L. Managing environmental matters. PPI (Pulp. Pap. Int.) 2001, 43, 32.

4. European Commission. Regulation (EC) No 761/2001 of the European Parliament and of the Council of 19 March 2001 allowing voluntary participation by organisations in a Community eco-management and audit scheme (EMAS). 2001. Available online: http:/ / eur-lex.europa.eu/legal-content/EN/TXT/PDF/?uri $=$ CELEX:32001R0761\&from=EN (accessed on 11 November 2015).

5. Jirillo, R.; Rocchi, A.; Martucci, O. EMAS and its local diffusion in Italy. Corp. Soc. Responsib. Environ. Manag. 2003, 10, 40-49. [CrossRef]

6. European Commission. Commission Decision of 4 March 2013 establishing the user's guide setting out the steps needed to participate in EMAS. Off. J. Eur. Union 2013, 56, 1-39. 
7. Stevens, P.A.; Batty, W.J.; Longhurst, P.J.; Drew, G.H. A critical review of classification of organisations in relation to the voluntary implementation of environmental management systems. J. Environ. Manag. 2012, 113, 206-212. [CrossRef] [PubMed]

8. European Commission. EMAS register-Reports \& Statistics, 2015. Available online: http://ec.europa.eu/ environment/emas/register/reports/reports.do (accessed on 20 February 2015).

9. NC State University. Writing A Literature Review and Using a Synthesis Matrix, NC State University Writing and Speaking Tutorial Service Tutors, 2006. Available online: http://tutorial.ncsu.edu/sites/ tutorial.ncsu.edu/files/synthesis matrix_CC.pdf (accessed on 18 December 2014).

10. Hillary, R. Pan-European Union assessment of EMAS implementation. Eur. Environ. 1998, 192, $184-192$. [CrossRef]

11. Pedersen, E.R. Perceptions of Performance: How European Organizations Experience EMAS Registration. Corp. Soc. Responsib. Environ. Manag. 2007, 73, 61-73. [CrossRef]

12. Abeliotis, K. A review of EMAS in Greece: Is It Effective? J. Clean. Prod. 2006, 14, 1644-1647. [CrossRef]

13. Christiansen, K.; Kardel, D. Environmental certificates-Danish lessons. J. Clean. Prod. 2005, 13, 863-866. [CrossRef]

14. Emilsson, S.; Hjelm, O. Implementation of standardised environmental management systems in Swedish local authorities: Reasons, Expectations and Some Outcomes. Environ. Sci. Pol. 2002, 5, 443-448. [CrossRef]

15. Bonilla Priego, M.J.; Najera, J.J.; Font, X. Environmental management decision-making in certified hotels. J. Sustain. Tour. 2011, 19, 361-381. [CrossRef]

16. Morrow, D.; Rondinelli, D. Adopting Corporate Environmental Management Systems:Motivations and Results of ISO 14001 and EMAS Certification. Eur. Manag. J. 2002, 20, 159-171. [CrossRef]

17. De la Espina, E.Z.D.; Velasco, C.B. Environmental management in the industrial enterprises of the south of Spain. Environ. Monit. Assess. 2000, 62, 169-174. [CrossRef]

18. Watson, M. Protecting the environment: The Role of Environmental Management Systems. J. R. Soc. Promot. Health 2006, 126, 280-284. [CrossRef] [PubMed]

19. Ifesi, A. Integration of EMS into national regulatory frameworks for offshore oil and gas production. UNEP Ind. Environ. 2003, 26, 89-94.

20. Kollman, K.; Prakash, A. EMS-based Environmental Regimes as Club Goods: Examining Variations in Firm-level Adoption of ISO 14001 and EMAS in U.K., U.S. and Germany. Pol. Sci. 2002, 35, 43-67. [CrossRef]

21. Perkins, R.; Neumayer, E. Europeanisation and the uneven convergence of environmental policy: Explaining the Geography of EMAS. Environ. Plan. C: Gov. Pol. 2004, 22, 881-897. [CrossRef]

22. Bracke, R.; Verbeke, T.; Dejonckheere, V. What Determines the Decision to Implement EMAS? A European Firm Level Study. Environ. Resour. Econ. 2008, 41, 499-518. [CrossRef]

23. Steger, U. Environmental management systems: Empirical Evidence and Further Perspectives. Eur. Manag. J. 2000, 18, 23-37. [CrossRef]

24. Kollman, K.; Prakash, A. Green by Choice?: Cross-National Variations in Firms' Responses to EMS-Based Environmental Regimes. World Polit. 2001, 53, 399-430. [CrossRef]

25. Wätzold, F.; Bultmann, A.; Eames, M.; Lulofs, K.; Schucht, S. EMAS and regulatory relief in Europe: Lessons from National Experience. Eur. Environ. 2001, 11, 37-48. [CrossRef]

26. Glachant, M.; Schucht, S.; Bültmann, A.; Wätzold, F. Companies' participation in EMAS: The Influence of the Public Regulator. Bus. Strateg. Environ. 2002, 11, 254-266. [CrossRef]

27. Steger, U.; Schindel, C.; Krapf, H. The experience of EMAS in three European countries: A Cultural and Competitive Analysis. Bus. Strateg. Environ. 2002, 11, 32-42. [CrossRef]

28. Wätzold, F. Explaining differences in EMAS participation rates across Europe: The Importance of Institutions, Incomplete Information and Path Dependence. Eur. J. Law Econ. 2009, 28, 67-82. [CrossRef]

29. Freimann, J.; Walther, M. The impacts of corporate environmental management systems: A Comparison of EMAS and ISO 14001. Greener Manag. Int. 2001, 36, 91-103. [CrossRef]

30. Tack, J.P. Environmental management systems and stakeholders: The Case of the Belgian Electricity Sector. Greener Manag. Int. 1999, 28, 50-58.

31. Whitford, A.B.; Tucker, J.A. Focal Points in Public Policy: Evidence from Voluntary Regulation. Rev. Policy Res. 2012, 29, 281-299. [CrossRef]

32. Neugebauer, F. EMAS and ISO 14001 in the German industry-complements or substitutes? J. Clean. Prod. 2012, 37, 249-256. [CrossRef] 
33. Heras, I.; Arana, G. Alternative models for environmental management in SMEs: The Case of Ekoscan vs. ISO 14001. J. Clean. Prod. 2010, 18, 726-735. [CrossRef]

34. Ransburg, B.; Vágási, M. Concepts and standards for the corporate internalization of sustainable development. Period. Polytech. Soc. Manag. Sci. 2007, 15, 43-51. [CrossRef]

35. Robèrt, K.-H. Tools and concepts for sustainable development, how do they relate to a general framework for sustainable development, and to each other? J. Clean. Prod. 2000, 8, 243-254. [CrossRef]

36. Robèrt, K.H.; Schmidt-Bleek, B.; Aloisi de Larderel, J.; Basile, G.; Jansen, J.L.; Kuehr, R.; Price Thomas, P.; Suzuki, M.; Hawken, P.; Wackernagel, M. Strategic sustainable development-Selection, design and synergies of applied tools. J. Clean. Prod. 2002, 10, 197-214. [CrossRef]

37. De Haes, H.A.U.; de Snoo, G.R. Environmental Certification Companies and Products: Two Vehicles for a Life Cycle Approach? Int. J. Life Cycle Assess. 1996, 1, 168-170. [CrossRef]

38. De Haes, H.A.U.; De Snoo, G.R. The agro-production chain environmental management in the agricultural production-consumption chain. Int. J. Life Cycle Assess. 1997, 2, 33-38. [CrossRef]

39. Ljungberg, L.Y. Materials selection and design for development of sustainable products. Mater. Des. 2007, 28, 466-479. [CrossRef]

40. Ammenberg, J.; Sundin, E. Products in environmental management systems: Drivers, Barriers and Experiences. J. Clean. Prod. 2005, 13, 405-415. [CrossRef]

41. Ardente, F.; Beccali, G.; Cellura, M.; Marvuglia, A. POEMS: A Case Study of an Italian Wine-Producing Firm. Environ. Manage. 2006, 38, 350-364. [CrossRef] [PubMed]

42. Hillary, R.; Thorsen, N. Regulatory and self-regulatory measures as routes to promote cleaner production. J. Clean. Prod. 1999, 7, 1-11. [CrossRef]

43. Fresner, J. Cleaner production as a means for effective environmental management. J. Clean. Prod. 1998, 6, 171-179. [CrossRef]

44. Rennings, K.; Ziegler, A.; Ankele, K.; Hoffmann, E. The influence of different characteristics of the EU environmental management and auditing scheme on technical environmental innovations and economic performance. Ecol. Econ. 2006, 57, 45-59. [CrossRef]

45. Ziegler, A.; Nogareda, J.S. Environmental management systems and technological environmental innovations: Exploring the Causal Relationship. Res. Pol. 2009, 38, 885-893. [CrossRef]

46. Helby, P. EKO-Energi-A public voluntary programme targeted at Swedish firms with ambitious environmental goals. J. Clean. Prod. 2002, 10, 143-151. [CrossRef]

47. Wysokinska, Z.; Witkowska, J. International Business and Environmental Issues-Some Empirical Evidence From Transition Economies. Pol. J. Enviorn. Stud. 2005, 14, 269-279.

48. Andrews, R.N.L. Environmental regulation and business "self-regulation”. Pol. Sci. 1998, 31, $177-197$. [CrossRef]

49. Mísařová, P.P. Development of environmental management accounting and EMAS over time. Acta Univ. Agric. Silvic. Mendelianae Brun. 2012, 60, 307-318. [CrossRef]

50. Pérez, E.A.; Ruiz, C.C.; Fenech, F.C. Environmental management systems as an embedding mechanism: A Research Note. Account. Audit. Account. J. 2007, 20, 403-422.

51. Erkko, S.; Melanen, M.; Mickwitz, P. Eco-efficiency in the Finnish EMAS reports-A buzz word? J. Clean. Prod. 2005, 13, 799-813. [CrossRef]

52. Mísařová, P.P. Evaluation studies of EMA implementation's barriers in business practice. Acta Univ. Agric. Silvic. Mendelianae Brun. 2010, 58, 319-328. [CrossRef]

53. Petrosillo, I.; De Marco, A.; Botta, S.; Comoglio, C. EMAS in local authorities: Suitable Indicators in Adopting Environmental Management Systems. Ecol. Indic. 2012, 13, 263-274. [CrossRef]

54. Gernuks, M.; Buchgeister, J.; Schebek, L. Assessment of environmental aspects and determination of environmental targets within environmental management systems (EMS)—development of a procedure for Volkswagen. J. Clean. Prod. 2007, 15, 1063-1075. [CrossRef]

55. Lewandowska, A. Environmental life cycle assessment as a tool for identification and assessment of environmental aspects in environmental management systems (EMS) part 1: Methodology. Int. J. Life Cycle Assess. 2011, 16, 178-186. [CrossRef]

56. Lewandowska, A.; Matuszak-Flejszman, A.; Joachimiak, K.; Ciroth, A. Environmental life cycle assessment (LCA) as a tool for identification and assessment of environmental aspects in environmental management systems (EMS): Part 2: Case Studies. Int. J. Life Cycle Assess. 2011, 16, 247-257. [CrossRef] 
57. Zobel, T. Characterisation of environmental policy implementation in an EMS context: A Multiple-Case Study in Sweden. J. Clean. Prod. 2008, 16, 37-50. [CrossRef]

58. Zobel, T.; Burman, J.O. Factors of importance in identification and assessment of environmental aspects in an EMS context: Experiences in Swedish Organizations. J. Clean. Prod. 2004, 12, 13-27. [CrossRef]

59. Marazza, D.; Bandini, V.; Contin, A. Ranking environmental aspects in environmental management systems: A New Method Tested on Local Authorities. Environ. Int. 2010, 36, 168-179. [CrossRef] [PubMed]

60. Liu, K.F.-R.; Ko, C.-Y.; Fan, C.; Chen, C.-W. Combining risk assessment, life cycle assessment, and multi-criteria decision analysis to estimate environmental aspects in environmental management system. Int. J. Life Cycle Assess. 2012, 17, 845-862. [CrossRef]

61. Liedtke, C.; Rohn, H.; Kuhndt, M.; Nickel, R. Applying Material Flow Accounting: Ecoauditing and Resource Management at the Kambiem Furniture Workshop. J. Ind. Ecol. 1999, 2, 131-147. [CrossRef]

62. Olsthoorn, X.; Tyteca, D.; Wehrmeyer, W.; Wagner, M. Environmental indicators for business: A Review of Literature and Standardization Methods. J. Clean. Prod. 2001, 9, 453-463. [CrossRef]

63. Honkasalo, A. The EMAS scheme: A Management Tool and Instrument of Environmental Policy. J. Clean. Prod. 1998, 6, 119-128. [CrossRef]

64. Ahsen, A.; Von Lange, C.; Pianowski, M. Corporate environmental reporting: Survey and Empirical Evidence. Int. J. Environ. Sustain. Dev. 2004, 3, 5-17. [CrossRef]

65. Herczeg, M. The role of corporate environmental statements. Period. Polytech. Soc. Manag. Sci. 2002, 10, 133-142.

66. Institute for Prospective Technological Studies. Best Environmental Management Practice, 2014. Available online: http:/ / susproc.jrc.ec.europa.eu/activities/emas/index.html (accessed on 7 March 2014).

67. European Commission. Regulation (EC) No 1221/2009 of the European Parliament and of the Council of 25 November on the voluntary participation by organisations in a Community eco-management and audit scheme (EMAS). 2009. Available online: http://eur-lex.europa.eu/legal-content/EN/TXT/PDF/? uri=CELEX:32009R1221\&from=EN (accessed on 11 November 2015).

68. Lara, R.G.; Martínez, E.F. Sistema Comunitario de Gestión y Auditoría Medioambientales (EMAS) aplicado a empresas del sector cerámico. Bol. Soc. Esp. Cerám. Vidr. 2010, 49, 335-339.

69. González, P.; Sarkis, J.; Adenso-Díaz, B. Environmental management system certification and its influence on corporate practices: Evidence from the Automotive Industry. Int. J. Oper. Prod. Manag. 2008, 28, 1021-1041. [CrossRef]

70. Darbra, R.M.; Ronza, A.; Casal, J.; Stojanovic, T.A.; Wooldridge, C. The Self Diagnosis Method: A New Methodology to Assess Environmental Management in Sea Ports. Mar. Pollut. Bull. 2004, 48, 420-428. [CrossRef] [PubMed]

71. Peris-Mora, E.; Orejas, J.M.D.; Subirats, A.; Ibáñez, S.; Alvarez, P. Development of a system of indicators for sustainable port management. Mar. Pollut. Bull. 2005, 50, 1649-1660. [CrossRef] [PubMed]

72. Tselentis, V.S. Marina Environmental Review System: A Methodology to Assess Environmental Management in Recreational Ports. Eur. Res. Stud. J. 2008, 11, 47-56.

73. Bonilla Priego, M.J.; Aviles Palacios, C. Analysis of Environmental Statements Issued by EMAS-Certified Spanish Hotels. Cornell Hosp. Q 2008, 49, 381-394. [CrossRef]

74. Botta, S.; Comoglio, C. Environmental management systems in local authorities: The Case Study of the Cesana Torinese Municipality, a Turin 2006 olympic site. Am. J. Environ. Sci. 2007, 3, 126-134. [CrossRef]

75. Bruzzi, L.; Boragno, V.; Serrano-Bernardo, F.A.; Verità, S.; Rosúa-Campos, J.L. Environmental management policy in a coastal tourism municipality: The Case Study of Cervia (Italy). Local Environ. Int. J. Justice Sustain. 2011, 16, 93-113. [CrossRef]

76. Cockrean, B. The local authority EMAS in the UK: The Sutton Model. Environmentalist 1997, 17, 11-13. [CrossRef]

77. Emilsson, S.; Hjelm, O. Different approaches to standardized environmental management systems in local authorities-two case studies in Gothenburg and Newcastle. Corp. Soc. Responsib. Environ. Manag. 2004, 11, 48-60. [CrossRef]

78. Emilsson, S.; Hjelm, O. Development of the Use of Standardized Environmental Management Systems (EMSs) in Local Authorities. Corp. Soc. Responsib. Environ. Manag. 2005, 156, 144-156. [CrossRef]

79. Mazzi, A.; Mason, C.; Mason, M.; Scipioni, A. Is it possible to compare environmental performance indicators reported by public administrations? Results from an Italian survey. Ecol. Indic. 2012, 23, 653-659. 
80. Ferreira, A.J.D.; Lopes, M.A.R.; Morais, J.P.F. Environmental management and audit schemes implementation as an educational tool for sustainability. J. Clean. Prod. 2006, 14, 973-982. [CrossRef]

81. Dettenkofer, M.; Kümmerer, K.; Schuster, A.; Mühlich, M.; Scherrer, M.; Daschner, F.D. Environmental auditing in hospitals: Approach and Implementation in an University Hospital. J. Hosp. Infect. 1997, 36, 17-22. [CrossRef]

82. Dettenkofer, M.; Kuemmerer, K.; Schuster, A.; Mueller, W.; Muehlich, M.; Scherrer, M.; Daschner, F.D. Environmental auditing in hospitals: First Results in a University Hospital. Environ. Manag. 2000, 25, 105-113. [CrossRef]

83. Dragomir, V.D. Eco-management and the paradigm of self-regulation. Environ. Eng. Manag. J. 2008, 7, 427-431.

84. Borsese, A.; McDowall, R.D.; Andrade, J.M. Communication: The Essential Factor When Implementing Management Systems. Accredit. Qual. Assur. 2003, 8, 2-12. [CrossRef]

85. Lannelongue, G.; González-Benito, J. Opportunism and environmental management systems: Certification as a Smokescreen for Stakeholders. Ecol. Econ. 2012, 82, 11-22. [CrossRef]

86. Hřebíček, J.; Soukopová, J.; Štencl, M.; Trenz, O. Corporate key performance indicators for environmental management and reporting. Acta Univ. Agric. Silvic. Mendelianae Brun. 2011, 59, 99-108. [CrossRef]

87. Jasch, C. Environmental performance evaluation and indicators. J. Clean. Prod. 2000, 8, 79-88. [CrossRef]

88. Rowland-Jones, R.; Pryde, M.; Cresser, M. An evaluation of current environmental management systems as indicators of environmental performance. Manag. Environ. Qual. An. Int. J. 2005, 16, 211-219. [CrossRef]

89. Iraldo, F.; Testa, F.; Frey, M. Is an environmental management system able to influence environmental and competitive performance? The case of the eco-management and audit scheme (EMAS) in the European union. J. Clean. Prod. 2009, 17, 1444-1452. [CrossRef]

90. Daddi, T.; Magistrelli, M.; Frey, M.; Iraldo, F. Do environmental management systems improve environmental performance? Empirical evidence from Italian companies. Environ. Dev. Sustain. 2011, 13, 845-862. [CrossRef]

91. International Organization for Standardization. Environmental Management Systems—Requirements with Guidance for Use; ISO 14001:2015; International Organization for Standardization: Geneva, Switzerland, 2015.

(C) 2016 by the authors; licensee MDPI, Basel, Switzerland. This article is an open access article distributed under the terms and conditions of the Creative Commons by Attribution (CC-BY) license (http:/ / creativecommons.org/licenses/by/4.0/). 